\title{
Electronic payment mechanisms II
}

\author{
by Stephen Mason
}

This two-part article considers the legal and regulatory issues relating to electronic payment mechanisms other than the usual forms of payment, such as cash, credit cards and debit cards.

\section{MONEY LAUNDERING}

\section{Electronic Money Directive}

$\Lambda$ lthough there are a range of regulatory controls in place to provide for the stability of financial institutions working within the financial markets, money laundering remains an important area of concern. As a consequence, the financial institutions are subject to the relevant regulations and laws in relation to money laundering. The Electronic Money Directive provides, in article 2(1), that an electronic money issuer is subject to the provisions of the Money Laundering Directive (Council Directive 91/308/EEC of 10 June 1991 on prevention of the use of the financial system for the purpose of money laundering (OJ 28/06/1991 L 166/77), as amended by Directive 2001/97/EC of the European Parliament and of the Council of 4 December 2001 amending Council Directive 91/308/EEC on prevention of the use of the financial system for the purpose of money laundering (OJ 28.12.2001 L 344/76).

Money laundering is defined in article 1 of the Money Laundering Directive as follows:

“"Money laundering'" means the following conduct when committed intentionally:

- the conversion or transfer of property, knowing that such property is derived from criminal activity or from an act of participation in such activity, for the purpose of concealing or disguising the illicit origin of the property or of assisting any person who is involved in the commission of such activity to evade the legal consequences of his action;

- the concealment or disguise of the true nature, source, location, disposition, movement, rights with respect to, or ownership of property, knowing that such property is derived from criminal activity or from an act of participation in such activity,

- the acquisition, possession or use of property, knowing, at the time of receipt, that such property was derived from criminal activity or from an act of participation in such activity,

- participation in, association to commit, attempts to commit and aiding, abetting, facilitating and counselling the commission of any of the actions mentioned in the foregoing paragraphs.

Knowledge, intent or purpose required as an element of the above-mentioned activities may be inferred from objective factual circumstances. Money laundering shall be regarded as such even where the activities which generated the property to be laundered were perpetrated in the territory of another Member State or in that of a third country."

\section{Legislation}

The offences relating to money laundering are contained in the Criminal Justice Act 1988, as inserted by the Criminal Justice Act 1993. The offences created are:

- to assist another to retain the proceeds of criminal conduct (section 93A);

- the acquisition, possession or use of the proceeds of criminal conduct (section 93B);

- concealing or transferring the proceeds of criminal conduct (section 93C).

Where a person discloses to another information about an investigation that is being, or is about to be, conducted into money laundering (section 93D).

In addition, the Money Laundering Regulations 1993 require any institution undertaking activities in "relevant financial business" to adopt the procedures set out in regulation 5. This is defined in regulation 4(e) as "any home regulated activity carried on by a European institution in respect of which the requirements of paragraph 1 of Schedule 2 to the Banking Coordination (Second Council Directive) Regulations 1992 have been complied with." 
The Banking Coordination (Second Council Directive) Regulations 1992 refers to the Second Council Directive 89/646/EEC of 15 December 1989 on the coordination of laws, regulations and administrative provisions relating to the taking up and pursuit of the business of credit institutions and amending Directive 77/780/EEC (OJ 30/12/1989 L 386/1). With respect to banks, this covers the activities listed in Annex I to the to the Banking Consolidation Directive, which now incorporates the Second Council Directive.

The procedures set out in regulation 5 are:

- identification procedures in accordance with regulations 7 and 9;

- to adopt record-keeping procedures in accordance with regulation 12 (normally to retain records for five years - see Financial Services Handbook, "Electronic Money", Schedule 1 Record keeping requirements);

- to provide appropriate internal reporting procedures in accordance with regulation 14 as may be appropriate for the purposes of forestalling and preventing money laundering;

- to introduce such other procedures of internal control and communication for the purposes of making employees whose duties include the handling of relevant financial business aware of the relevant procedures and provide employees with training in the recognition and handling of transactions carried out by, or on behalf of, any person who is, or appears to be, engaged in money laundering.

In addition, the Money Laundering Regulations 2001 provide for the registration of money service operators with the Commissioners of Customs and Excise. The Money Laundering Regulations 2001 aim to give effect to articles 12 and 15 of the Money Laundering Directive and add additional activities to the meaning of relevant financial business to include, in regulation 3(2)(a) "transmitting money, or any representation of monetary value, by any means." The Treasury proposed a revision of the Regulations in November 2002, and a draft statutory instrument has been prepared with a view to consolidate, clarify and update the existing Regulations and to implement the requirements of the Money Laundering Directive as revised.

\section{Regulations}

The Financial Services Authority has published the Money Laundering Rules to comply with its statutory obligation to contribute to the reduction of financial crime, as set out in section 2(2)(c) of the Financial Services and Markets Act 2000. These rules are a regulatory requirement, and firms undertaking regulated activities are required to follow the rules in addition to the provisions of the regulations (a number of specified firms are excluded from the Rules by para 1.1.2R). In many respects the rules and the regulations are complementary to each other, although the Joint Money Laundering Steering Group, which is made up of a number of trade associations in the financial services industry, has issued guidance notes on the application of the Regulations.

Compliance with the guidance notes is not mandatory, but under the provisions of regulation 3 of the Money Laundering Regulations 1993, a judge may have regard to any relevant supervisory or regulatory guidance which applies, which will include the rules and guidance notes.

The not unreasonable provisions relating to money laundering tend to negate the notion that electronic money can be a substitute for money in the form of coins or bank notes. Either electronic money is to be similar to coins or bank notes and have the attribute of anonymity, or it should be subject to the same controls as any other form of money not circulating in the form of coins or bank notes. A further indication of the anonymity of electronic money is demonstrated by the requirement of the issuer, in accordance with article 7(2)(c) of the Payments Recommendation, to keep

“...for a sufficient period of time, internal records to enable the transactions referred to in Article 1 (1) to be traced and errors to be rectified."

On balance, it appears that electronic money cannot be considered a "surrogate for coins and bank notes" as suggested in recital 3 to the Electronic Money Directive, because it lacks the attribute of anonymity associated with the physical manifestation of money.

\section{CONSUMER PROTECTION}

The regulation of trading terms to payment instrument contracts was initially attempted by way of the Payments Recommendation (Commission Recommendation of 30 July 1997 concerning transactions by electronic payment instruments and in particular the relationship between issuer and holder 97/489/EC OJ 02/08/1997 L 208/52). Although the Payments Recommendation has no binding effect on Member States, nevertheless many of its provisions are implemented in the Banking Code, which in itself is voluntary, and only applies to banks and building societies (The electronic purse is discussed in paragraphs 12.12 to 12.14 in the Banking Code, March 2003. Note also the Guidance for Subscribers that states at page 44 "Although the electronic purse is not yet a product in common use, the provisions remain in the Code at the request of $\mathrm{HM}$ Treasury to comply with EU requirements)."

However, a minimum set of rules have been introduced with the Distance Selling Directive (Directive (EC) 7/97 of the European Parliament and of the Council of 20 May 1997 on the protection of consumers in respect of distance contracts - OJ 20/05/1997 L 144/19) and the Directive 2002/65/EC of the European Parliament and of the 
Council of September 23, 2002 concerning the distance marketing of consumer financial services (Direct Financial Services Directive - Directive 2002/65/EC of the European Parliament and of the Council of 23 September 2002 concerning the distance marketing of consumer financial services and amending Council Directive 90/619/EEC and Directives 97/7/EC and 98/27/EC (OJ 9.10.02 L217/16).

These Directives act to regulate the relationship between consumer and provider in addition to the regulatory framework that already exists, including Council Directive 93/13/EEC of 5 April 1993 on unfair terms in consumer contracts (OJ 21/04/1993 L 095/29) (Unfair Terms in Consumer Contracts Directive) and the regulations issued under the provisions of this Directive, together with the Unfair Contract Terms Act 1977.

The Direct Financial Services Directive applies to consumers (Recitals 23, 24 and 25 - a definition is provided in article 2(d)) and covers, in accordance with recital 14, "all financial services liable to be provided at a distance" and includes intermediaries (recital 19). In accordance with the provisions of article 21, Member States are required to bring the Directive into force not later than October 9, 2004.

For the purposes of the Directive, a "distance contract" means:

"any contract concerning financial services concluded between a supplier and a consumer under an organised distance sales or service-provision scheme run by the supplier, who, for the purpose of that contract, makes exclusive use of one or more means of distance communication up to and including the time at which the contract is concluded;"

The definition of "financial service" is sufficiently wide in scope to include the provision of electronic money: ... "means any service of a banking, credit, insurance, personal pension, investment or payment nature;"

\section{Information to be provided before the conclusion of the contract}

Similar provisions that apply under the provisions of the Distance Selling Directive also apply in relation to the sale of financial services at a distance. They include information concerning the supplier, the service and the contract.

Information concerning the supplier

The following information must be provided in "good time" before the consumer is bound by an offer made at a distance, as required by article 3(1)(1):

"(a) the identity and the main business of the supplier, the geographical address at which the supplier is established and any other geographical address relevant for the customer's relations with the supplier;

(b) the identity of the representative of the supplier established in the consumer's Member State of residence and the geographical address relevant for the customer's relations with the representative, if such a representative exists;

(c) when the consumer's dealings are with any professional other than the supplier, the identity of this professional, the capacity in which he is acting vis-à-vis the consumer, and the geographical address relevant for the customer's relations with this professional;

(d) where the supplier is registered in a trade or similar public register, the trade register in which the supplier is entered and his registration number or an equivalent means of identification in that register;

(e) where the supplier's activity is subject to an authorization scheme, the particulars of the relevant supervisory authority (article 3(1)(1));”

Information concerning the service

Article 3(1)(2) sets out the range of information that must be provided about the service, including, for the purposes of supplying electronic money in the form of travellers' cheques, item (c) below:

"(a) a description of the main characteristics of the financial service [see article 3(3) and(4) of the Payments

Recommendation for details of the information to be given to a consumer in relation to an electronic payments instrument];

(b) the total price to be paid by the consumer to the supplier for the financial service, including all related fees, charges and expenses, and all taxes paid via the supplier or, when an exact price cannot be indicated, the basis for the calculation of the price enabling the consumer to verify it;

(c) where relevant notice indicating that the financial service is related to instruments involving special risks related to their specific features or the operations to be executed or whose price depends on fluctuations in the financial markets outside the supplier's control and that historical performances are no indicators for future performances;

(d) notice of the possibility that other taxes and/or costs may exist that are not paid via the supplier or imposed by him;

(e) any limitations of the period for which the information provided is valid;

(f) the arrangements for payment and for performance;

(g) any specific additional cost for the consumer of using the means of distance communication, if such additional cost is charged;"

Information concerning the contract

Article 3(1)(3) lists additional items of information that must be provided:

- whether there is a right of withdrawal in accordance with Article 6 and, if such a right exists, how long it lasts and what conditions must be adhered to in exercising it, including information on the amount which the consumer may be required to pay in 
accordance with Article 7(1), as well as the consequences of failing to exercise the right;

- the minimum duration of the distance contract in fulfillment of which financial services are to be performed permanently or recurrently;

- the ability to terminate the contract early or unilaterally by virtue of the terms of the distance contract, including any penalties;

- practical instructions to enable a consumer to exercise the right of withdrawal indicating, amongst other things, the address to which the notification of a withdrawal should be sent;

- which laws are taken by the supplier as a basis for the establishment of relations with the consumer before the distance contract is concluded;

- clauses relating to applicable law and competent court;

- the language or languages used to set out the contractual terms and conditions, the prior information and continuing communications during the course of the contract.

The supplier is also required to inform the consumer whether:

- there is a right of redress, other than through a court (article 3(4)(a));

- what, if any, compensation arrangements or guaranteed funds are available (article 3(4)(b).

The commercial purpose of the offer must be made clear, and the information required to be provided under the terms of article 3 must be provided, in accordance with article 3(2), in "a clear and comprehensible manner in any way appropriate to the means of distance communication used, with due regard, in particular, to the principles of good faith in commercial transactions, and the principles governing the protection of those who are unable, pursuant to the legislation of the Member States, to give their consent, such as minors." Article 4 provides that where there are other legislative requirements relating to the provision of prior information when selling financial services, any such requirements will be additional to those that apply under the Direct Financial Services Directive.

\section{Communication of the contract terms}

The supplier is required to communicate, in accordance with the provisions of article 5(1), the contractual terms and conditions on paper or on another durable medium available and accessible to the consumer in good time and before the contract is concluded. In addition, the consumer may request, as provided by article 5(3), the terms and conditions at any time during the contract and may change the means of communication used, unless the method chosen is incompatible with the contract or the nature of the service.

\section{Withdrawal from the contract}

The consumer has the right to withdraw from the distance contract. The consumer has 14 calendar days in which to withdraw from the contract, and can do so without giving a reason and without penalty, although article 6(2) lists a number of financial services to which the right of withdrawal does not apply, as set out in article 6(1). The period for withdrawal begins:

- "either from the day of the conclusion of the distance contract, except in respect of the said life assurance, where the time limit will begin from the time when the consumer is informed that the distance contract has been concluded, or

- from the day on which the consumer receives the contractual terms and conditions and the information in accordance with Article 5(1) or (2), if that is later than the date referred to in the first indent."

In the event the consumer exercises their rights to withdraw from the contract, they are required to inform the supplier at the address indicated by the supplier under the provisions of article 3(1)(3)(d) - article 6(6). Where a consumer withdraws from the contract under the provisions of article 6(1), the supplier may only charge the consumer for the service actually provided in accordance with the contract. The supplier may only make such a charge where it informed the consumer of their right to withdraw from the contract in accordance with article 3(1)(3)(a), and they were informed of the amount they may be required to pay under the provisions of article 7(1).

\section{Information subsequent to a transaction}

The Payments Recommendation requires a certain amount of information to be provided to the holder of an electronic payment instrument, as set out in article 4:

"(a) a reference enabling the holder to identify the
transaction, including, where appropriate, the information
relating to the acceptor at/with which the transaction took
place;

(b) the amount of the transaction debited to the holder in billing currency and, where applicable, the amount in foreign currency;

(c) the amount of any fees and charges applied for particular types of transactions. The issuer also provides the holder with the exchange rate used for converting foreign currency transactions.

2. The issuer of an electronic money instrument provides the holder with the possibility of verifying the last five transactions executed with the instrument and the outstanding value stored thereon".

The text of paragraph 2 to article 4 is relevant to the ability of the customer to keep a check on the use of their electronic money. This is one way by which the customer is 
able to verify their transactions and identify whether their electronic money has been used without authority.

\section{Obligations of the parties}

The Payments Recommendation places obligations on both the issuer and the holder in relation to the payment instrument. The liabilities of the holder are set out in article 5, where the holder:

“(a) uses the electronic payment instrument in accordance with the terms governing the issuing and use of a payment instrument; in particular, the holder takes all reasonable steps to keep safe the electronic payment instrument and the means (such as a personal identification number or other code) which enable it to be used;

(b) notifies the issuer (or the entity specified by the latter) without delay after becoming aware of:

- the loss or theft of the electronic payment instrument or of the means which enable it to be used,

- the recording on his/her account of any unauthorized transaction,

-any error or other irregularity in the maintaining of that account by the issuer;

(c) does not record his personal identification number or other code in any easily recognizable form, in particular on the electronic payment instrument or on any item which he/she keeps or carries with the electronic payment instrument;

(d) does not countermand an order which he/she has given by means of his/her electronic payment instrument, except if the amount was not determined when the order was given".

The provisions of article 5(d) must be considered in the light of article 6 of the Direct Financial Services Directive, which gives a consumer the right to withdraw from a distance contract without penalty for a period of 14 calendar days after the contract is concluded.

The obligations of the issuer are set out in article 7 , including the right to alter contract terms with sufficient notice; not to disclose the holder's personal identification number or other code to anybody other than the holder; not to send an unsolicited electronic payment instrument except to replace such an instrument already held by the holder; to retain internal records to enable transactions to be traced and rectified; to enable the holder to notify the issuer of any incidents that the holder is required to inform the issuer about under the terms of article 5(b) and, in the event of a dispute, to adduce evidence that a transaction was accurately recorded and entered into accounts and was not affected by technical breakdown or other deficiency.

\section{Liabilities of the parties}

The liabilities of the holder of an electronic payment instrument are set out in article 6 of the Payments Recommendation. This provides that up to the time of notification, the holder bears any losses related to the electronic payment instrument up to a limit, which may not exceed ECU 150, although the Banking Code has a lower limit of $£ 50$. This limit does not apply where the holder acted with extreme negligence, in contravention of the provisions under article 5 (a), (b) or (c), or fraudulently. Once the holder has notified the issuer of the loss, the holder is no longer liable. In addition, the holder is not liable where the instrument is used on-line without the physical presentation of the instrument or electronic identification under the provisions of article 6(3).

Further, the holder does not become liable where the confidential code or any other similar proof of identity is used to obtain access to the payment instrument. Although this latter provision has not been incorporated into the Banking Code or any other form of regulation in domestic law, it is a powerful argument to prevent issuers from failing to provide adequate security measures when a payment instrument is used on-line.

The introduction of the Distance Selling Directive has served to amend some of the provisions of the Payments Recommendation, especially the provisions of article 6 , in that article 8 of the Distance Selling Directive allows a consumer to cancel a payment where fraudulent use has been made of a payment card, and any sums deducted are to be reimbursed. This amendment is not reflected in the Banking Code, which states, at paragraph 12.13, that a holder of an electronic purse will be liable for the first $£ 50$ of unauthorized withdrawals. If the Banking Code is correct, then the holder's liability is identical to the loss of cash. Article 8 of the Distance Selling Directive relates to "a payment card", the meaning of which is not defined. Whilst the position in relation to electronic money stored in an electronic purse is not clear, it may be possible to argue that payment card includes an instrument incorporating electronic money within the meaning of the Distance Selling Directive. Regulation 21(6) of the Consumer Protection (Distance Selling) Regulations 2000 (Statutory Instrument 2000 No 2334) defines "payment card" to include credit cards, charge cards, debit cards and store cards).

If an electronic payment instrument does not come within this definition, it is doubtful whether article 8 of the Distance Selling Directive applies to electronic payment cards. In any event, electronic payment instruments issued by banks do not come within annex II of the Distance Selling Directive or schedule 2 of the Consumer Protection (Distance Selling) Regulations 2000.

The liabilities of the issuer, which are subject to articles 5, 6, 7(2)(a) and (e), are set out in article 8, as follows:

"(a) for the non-execution or defective execution of the holder's transactions referred to in Article 1 (1), even if a transaction is initiated at devices/terminals or through equipment which are not under the issuer's direct or exclusive control, provided that the transaction is not initiated at 
devices/terminals or through equipment unauthorized for use by the issuer;

(b) for transactions not authorized by the holder, as well as for any error or irregularity attributable to the issuer in the maintaining of the holder's account".

The issuer is liable to the holder of the electronic money instrument for the total amount of the value stored on the instrument and for the defective execution of the holder's transactions, where the loss is attributable to the malfunction of the instrument, of the device or terminal, or any equipment that is used with authority, providing that the malfunction was not caused knowingly by the holder or in breach of article 3(3)(a) - article 8(4). The quantum of liability, as provided for in article 8(2), includes the amount of the unexecuted or defectively executed transaction and any interest thereon, and the amount required to restore the holder to the position they were in before the unauthorized transaction took place. Matters relating to claims for any additional type of loss, including further financial consequences, will be treated in accordance with the law that applies to the contract concluded between the parties, as set out in article 8(3).

In the event of a dispute over a transaction, article 7(e) provides that the burden of proving the transaction was recorded accurately is on the issuer. The Banking Code has similar provisions at paragraph 12.10. The Distance Selling Directive left this issue to Member States (article 11(3)(a)), and regulation 21(3) of the Consumer Protection (Distance Selling) Regulations 2000 provides that where a consumer alleges that the payment card was used without their authority, it is for the issuer of the card to prove it was authorized by the consumer.

The Payments Recommendation was the subject of a study in 2001 (Jean Herveg, Jean-François Lerouge, Anne Salaün, Laura Edgar, Chris Reed, Sonia Gonzalo and Dominique Spaey, Study on the implications of Recommendation 97/489/EC, 17 April 2001). This identified a number of problems in relation to the Recommendation's aim to create transparency of conditions for transactions: issuers failed to provide sufficient information to holders; the information that was provided lacked clarity, or was not easily available, or both lacked clarity and was not easily available; issuers failed to provide information at the appropriate time; and levels of compliance on this matter differed according to the type of electronic payment instrument (EPI).

Issuers often fail to comply with the Recommendation in relation to the obligations and liabilities of the parties to the contract in the following respects:

"5.2.1 Failure to limit a holder's liability after notification;

5.2.2 Failure to restrict liability when the EPI is used without physical presentation or electronic identification;
5.2.3 Lack of uniformity in relation to what constitutes gross negligence across the Member States;

5.2.4 Notification period for changes to the contract is often less than 1 month;

5.2.5 Countermanding provisions for unspecified sums are very rare;

5.2.6 Failure to provide for the liability of the issuer for defective or non-executed transactions.

5.3 Many issuers do not comply with the Recommendation in respect of the procedure for notification of loss or theft and the issuer's liability after notification:

5.3.1 Some issuers do not explain the notification procedures;

5.3.2 In many cases no special means are provided to prove that the notification has been made;

5.3.3 Some issuers offer only limited access to notification systems, eg by restricting operating hours.

5.4 In most Member States the burden of proof is placed on holders, or at best not stated in the EPI contract terms.

5.5 The means for settlement of disputes are inadequate in that:

5.5.1 Contracts often make no reference to dispute resolution bodies nor provide their contact details;

5.5.2 Dispute resolution bodies are often internal, and thus lack independence;

5.5.3 Costs of judicial action are prohibitively high, and the procedure extremely slow".

Jean Herveg, in Study on the implications of Recommendation 97/489/EC, defines electronic money instruments at page 21 as: "Reloadable payment instrument which stores monetary value and from which an amount is deducted each time a payment is made. The reloadable character of the instrument allows it to be reloaded with new monetary units each time it is needed." On the same page she defines electronic tokens as: "Monetary value stored on the memory of a computer that allows payment to be made in a digital environment like the Internet”.

The main problems identified by her in relation to electronic money instruments and electronic tokens are in the case of electronic money instruments:

"- lack of information provided to holders,

- limitations of the holder's liability are not always respected in case of loss or fraudulent use,

- a 24 hours a day notification service does not always exist and the holder receives no means to prove the notification,

- in most cases, the burden of proof lies on issuers,

- compliance is not complete for the settlement disputes,

- Denmark is the only country that appears to be fully

compliant with the Recommendation." 
The main issues in relation to electronic tokens (which are only available in four countries according to Herveg) are:

\section{"- no maximum amount of liability (although liability is limited itself by the storage limit);}

- no requirement regarding the means to prove the notification;

- no reversal of the burden of proof in favour of the holder."

The findings of this report illustrate that the issuers are failing to abide by the terms of the Payments Recommendation, which only acts to increase the exposure of issuers to the general laws on Member States relating to unfairness in contract terms in any event. Whilst there has been a great deal of activity to resolve payments electronically, the systems provided by operators must, of necessity, be "closed" and only open to subscribing parties. It does not appear that electronic money will have the same attributes as money in its physical manifestation, such as cash or bank notes.

\section{(C) Stephen Mason, 2004}

www.stpaulschambers.com

Stephen is barrister and the author of Electronic Signatures in Law (LexisNexis Butterworths, 2003) and E-mail and the internet at work: a concise guide to the legal issues (Pario Communications Limited, 4th edn, 2004). Stephen specializes in advising organizations in relation to their e-risks.

\section{SALS News}

\section{Civil justice system "can only get worse" says Brooke}

The UK civil justice system is in crisis with no prospect of recovery in sight according to Lord Justice Brooke, who made the criticism when delivering the SALS 2004 Annual Lecture at Charles Clore House on November 24, 2004.

In his lecture, entitled "Court modernisation and the crisis facing our civil courts", Lord Justice Brooke traced recent problems back to July 2002 when the Treasury declined support for a well-designed plan to relieve the serious problems faced by the civil and family courts. In addition to being Vice President of the Civil Division of the Court of Appeal, Lord Justice Brooke served until June 2004 as the judge in charge of modernising the courts.

The transcript of the lecture is published on page 2 of this issue of Amicus Curiae.

\section{Lord Goldsmith is guest speaker at annual dinner}

The Rt Hon The Lord Goldsmith QC (pictured) was guest speaker at the 2004 annual dinner of the Society for Advanced Legal Studies, which was held at the Hotel Russell on November 24, 2004.

Lord Goldsmith was introduced by Professor Harry Rajak, of Sussex Law School, University of Sussex, and a member of the Executive Committee of SALS. A vote of thanks was given by Professor Avrom Sherr, Director of the Institute of Advanced Legal Studies. Professor David Hayton of King's College, London, a member of the Advisory Council of the Institute of Advanced Legal
Studies, proposed a toast to the Society. Lord Goldsmith's speech is reproduced below.

"I am delighted to have been asked to speak at this dinner. The Society for Advanced Legal Studies provides an invaluable forum to promote greater cooperation between scholars of law and practitioners. This is an important objective.

"There is an old rhyme: 'You can always tell a barber by the way he parts his hair; You can always tell a dentist when he's in the dentist's chair; and even a musician you can tell him by his touch; you can always tell a lawyer but you cannot tell him much'. I think it true that practitioners of law, especially those who consider themselves expert in a given field,

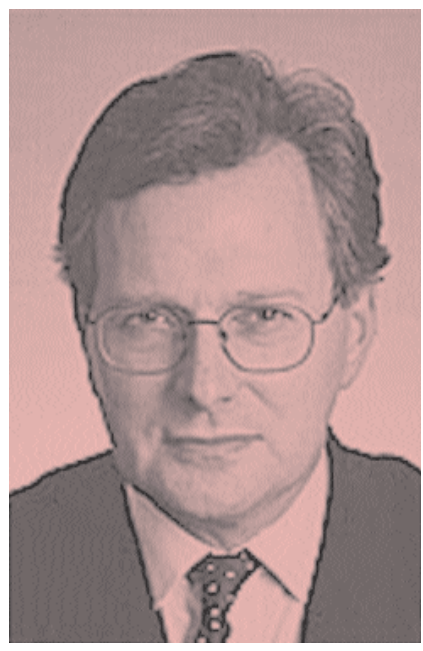
may often take the view that there is not much they can be told, especially by academics. Many other legal jurisdictions do not take the same view. It is very good that there have been real changes - as reading some judgements in the House of Lords, for example, make only too clear and this Society has a real part to play in this.

"The other reason for pleasure at being here is that my wife and I both studied at the Institute with which the society is connected doing Master's degrees at the University of London. We are both very pleased to be here as the Society's guests. 